\title{
PREDIKSI INTERAKSI MOLEKULER CAPE DENGAN IL-2, CD25, IL-10, CTLA-4, IDO, TGF $\beta$, and CCL2 DENGAN SOFTWARE DOCKING MOLEKULER
}

\author{
Zauhani Kusnul \\ *Akademi Keperawatan Pamenang \\ Correspondence Author: zauhani.kusnul@gmail.com
}

\begin{tabular}{|c|c|}
\hline Info Artikel : & ABSTRAK \\
\hline $\begin{array}{ll}\text { Sejarah Artikel : } \\
\text { Menerima } & 10-12-2018 \\
\text { Revisi } & 09-01-2018 \\
\text { Diterima } & 21-01-2019 \\
\text { Online } & 03-02-2019\end{array}$ & $\begin{array}{l}\text { The use of herbal medicine as a nutritious ingredient to treat various } \\
\text { diseases is still mostly done traditionally based on hereditary information. } \\
\text { The development of technology supports the exploration of natural } \\
\text { materials as a nutritious material with various scientific evidences. The } \\
\text { development of computational and bioinfrmatic technology simulates } \\
\text { interactions between various active compounds and target molecules } \\
\text { virtually commonly known as molecular docking, a virtual screening } \\
\text { based on structure used to predict the interaction of three-dimensional } \\
\text { structures of small molecules (compounds) with the target molecular } \\
\text { structure. Propolis is a substance produced by bees from resins collected } \\
\text { from plants and combined with wax and secretions from bee salivary } \\
\text { glands which are rich in various enzymes. In the world of medicine, } \\
\text { propolis has been used since time immemorial and until now it has been } \\
\text { known that propolis can be a natural medicine with anti-bacterial, anti- } \\
\text { tumor, antioxidant and immunomodulatory abilities. Molecular docking } \\
\text { between one of the active compounds in propolis, namely caffeic acid } \\
\text { phenethyl ester (CAPE) with various target molecules such as IL-2, CD25, } \\
\text { IL10, TGF } \beta \text {, CTLA-4, CCL21, and IDO using the DockingServer software } \\
\text { provides information that CAPE has inhibitory activity against IL-2, } \\
\text { CD25, IL-10, CTLA-4, IDO, TGF } \beta \text {, and CCL2 so that it has the potential } \\
\text { to be further developed as a candidate for immunomodulatory therapy. }\end{array}$ \\
\hline
\end{tabular}

\section{INTISARI}

\author{
Kata Kunci : \\ Docking molekuler, \\ propolis, CAPE, \\ molekul target
}

Penggunaan jamu sebagai bahan berkhasiat untuk mengobati berbagai penyakit masih banyak dilakukan secara tradisional berdasarkan informasi turun temurun. Perkembangan teknologi menunjang upaya eksplorasi bahan alam sebagai bahan berkhasiat dengan berbagai pembuktian ilmiah. Perkembangan teknologi komputasi dan bioinfrmatika membuat simulasi interaksi antara berbagai senyawa aktif dan molekul target secara virtual yang biasa dikenal dengan istilah docking molekuler, merupakan screening virtual berdasaarkan struktur yang digunakan untuk memprediksi interaksi struktur tiga dimensi molekul kecil (senyawa) dengan struktur molekul target. Propolis merupakan substansi yang dihasilkan oleh lebah dari resin yang dikumpulkan dari tanaman dan dikombinasikan dengan wax dan sekresi dari kelenjar ludah lebah yang kaya akan kandungan berbagai enzim. Dalam dunia pengobatan, propolis sudah digunakan sejak dahulu kala dan hingga kini telah diketahui propolis bisa menjadi obat alami dengan kemampuan anti bakteri, anti tumor, antioksidan, dan imunomodulator. Docking molekuler antara salah satu senyawa aktif dalam propolis yaitu caffeic acid phenethyl ester (CAPE) dengan berbagai molekul target seperti IL-2, 
CD25, IL10, TGF, CTLA-4, CCL21, dan IDO dengan menggunakan piranti lunak DockingServer memberikan informasi bahwa CAPE memiliki aktifitas inhibisi terhadap IL-2, CD25, IL-10, CTLA-4, IDO, $T G F \beta$, dan CCL2 sehingga berpotensi untuk dikembangkan lebih lanjut sebagai kandidat terapi imuomodulator terhadap kanker.

\section{PENDAHULUAN}

Secara praktis dalam keseharian kehidupan masyarakat Indonesia, pemanfaatan bahan alam untuk tujuan terapi sudah sangat lazim digunakan. Dalam kajian ilmiah keilmuan, khasiat/efek yang dihasilkan suatu bahan alam dapat ditelusuri dan dibuktikan sehingga dapat menjelaskan berbagai hal terkait mekanisme suatu bahan alam hingga menimbulkan efek terapi, dosis optimal, juga kemungkinan efek samping yangbditimbulkan. Hingga kini masih banyak mekanisme efek terapi dari bahan alam yang belum dapat diungkap dengan jelas. Dengan perkembangan tehnologi saat ini telah banyak dikembangkan piranti lunak yang mengintegrasikan berbagai bidang keilmuan seperti kimia, biologi, tehnologi komputasi dan bioinfrmatika untuk membuat simulasi interaksi antara berbagai senyawa aktif dan molekul target secara virtual yang biasa dikenal dengan istilah docking molekuler (Heo et al., 2014). Docking molekuler merupakan screening virtual berdasaarkan struktur (structure-based virtual screening /SBVS) yang digunakan untuk memprediksi interaksi struktur tiga dimensi molekul kecil (senyawa) dengan struktur molekul target (Mahajan, Gill dan Arora, 2014).

Aplikasi docking molekuler memberi manfat penting bagi bidang ilmu farmasi dan kedokteran, terutama dalam pengembangan obat baru. Dengan docking molekuler dapat diperkirakan nilai energi ikatan (free energy of binding) terkecil yang menggambarkan tingkat kecocokan ligan dengan senyawa target. Hasil dari docking molekuler dapat menjadi informasi yang membantu penelitian laboratorium menjadi lebih efisien (Mahajan, Gill dan Arora, 2014)(Mahajan, et al., 2014). Namun sebagai sebuah metode, docking molekuler juga msih terus dikembangkan.

Beberapa informasi dari hasil proses docking diantaranya, free energy of binding yang artinya adalah jumlah/besar energi yang dibutuhkan ligan untuk berikatan dengan reseptor; makin kecil nilai free energy of binding menunjukkan prediksi potensi aktifitas ligan/substrat makin tinggi; inhibition concentration artinya konsentrasi ligan/substrat yang dibutuhkan untuk menghambat reseptor, makin kecil nilai inhibition concentration menunjukkan prediksi potensi aktifitas substrat makin tinggi, bila suatu proses docking tidak memberikan hasil nilai inhibition concentration maka kemungkinan senyawa tersebut bersifat agonis terhadap target; total intermolecular energy artinya total energi yang dibutuhkan dalam proses interaksi ligan reseptor, makin kecil nilai total intermolecular energy menunjukkan prediksi kemungkinan kecocokan interaksi ligan dengan reseptor makin tinggi; interaction surface artinya luas permukaan penempelan ligan dan reseptor, makin luas permukaan penempelan menunjukkan potensi interaksi ligan reseptor makin baik .

Hingga saat ini telah dilakukan kajian terhadap berbagai jenis bahan alam terkait potensinya sebagai agen imunoterapi, salah satunya yang dilaporkan memiliki aktifitas sebagai imunomoduator adalah propolis. Propolis merupakan substansi yang dihasilkan oleh lebah dari resin yang dikumpulkan dari tanaman dan dikombinasikan dengan wax dan sekresi dari kelenjar ludah lebah yang kaya akan kandungan berbagai enzim (Sawaya, Barbosa da Silva Cunha dan Marcucci, 2011). Propolis digunakan lebah untuk melapisi dinding sarang untuk melindungi dari masuknya binatang penyerang dari luar, menghambat pertumbuhan bakteri dan jamur, memperkuat dinding sel juga menjaga lingkungan aseptik dalam sarang (Salatino et al., 2005).

Dalam dunia pengobatan, propolis sudah digunakan sejak dahulu kala dan hingga kini telah diketahui propolis bisa menjadi obat alami dengan kemampuan anti bakteri (Hasson, 2014), anti tumor (Borges et al., 2011; Khacha-ananda et al., 2013), antioksidan (Padmavathi et al., 2006), dan imunomodulator (Sforcin, Kaneno dan Funari, 2011; Kusnul et al., 2017). 
Penelitian ini mengeksplorasi interaksi molekul antara salah satu senyawa aktif dalam propolis yaitu caffeic acid phenethyl ester (CAPE) dengan berbagai molekul target seperti IL-2, CD25, IL10, TGF $\beta$, CTLA-4, CCL21, dan IDO dengan menggunakan piranti lunak DockingServer. Pemilihan molekul target tersebut berdasarkan peran dan keterkaitanya dengan sel Treg. Adapun sekilas tentang molekul target adalah sebagai berikut;

- IL-2 merupakan faktor penting dalam pembentukan dan aktifitas supresi sel Treg dan karena sel Treg tidak memproduksi IL-2 sendiri maka sel Treg bergantung pada produksi dan ekspresi IL-2 oleh sel T responder (sel T non sel Treg di lingkup sekitar sel Treg) (Rosa et al., 2004).

- CD25/IL2R diekspresikan secara konstitutif pada kadar yang tinggi oleh sel Treg (CD4+CD25+ FoxP3+), hal ini memudahkan sel Treg untuk mendapatkan IL-2 yang penting untuk fungsi supresinya (Feinerman et al., 2010).

- CTLA-4 (CD152) merupakan molekul ko-stimulator yang diekspresikan secara konstitutif oleh sel Treg (CD25+). CTLA-4 menghambat sel T efektor dengan berikatan dengan CD80/86 (B7) yang diekspresikan APC (Tran et al., 2010). Interaksi/ikatan CTLA-4 dan B7 menunjang kemampuan sel Treg untuk memacu sel dendritik memproduksi indolamin 2,3dioxgenase (IDO) sehingga terjadi akumulasi IDO pada area tumor dan menggganggu respon imun anti tumor (Roy et al., 2013).

- $\quad$ IDO diekspresikan oleh sel dendritik yang imatur (Roy et al., 2013), juga oleh sel tumor (Curti et al., 2007). IDO merupakan enzim intraseluler yang bekerja mendegradasi tryptophan, serotonin, dan melatonin. Tryptophan merupakan asam amino esensial yang penting dalam proliferasi sel, deplesi tryptophan menyebabkan hambatan pada aktifitas sel T. Tryptophan yang terdegradasi menghasilkan kynurenin yang juga dapat menginduksi apoptosis sel $\mathrm{T}$ melalui mekanisme radikal bebas (Chen dan Guillemin, 2010).

- CCL21 diekspresikan beberapa jenis tumor/kanker, diantaranya; kanker lambung (Zhou et al., 2013), kanker primer dan metastasis sel kanker squamous cell carcinoma of the head and neck (SCCHN) (Wang et al., 2004) dan kanker serviks (Kodama et al., 2007). CCL21 dapat menginduksi AICD (activation induced cell death) sel T CD4 melalui peningkatan ekspresi FasL, caspase 8 dan caspase 9 (Yasuda et al., 2006).

- TGF $\beta$ berperan penting dalam mekanisme escape dari immunosurveillance, juga dalam proses diferensiasi dan konversi sel aTreg (Peghini et al., 2012). TGF $\beta$ bekerja menghambat aktivitas CTL, sel T CD4+, Makrofag, sel dendritik, dan sel NK. TGF $\beta$ menghambat aktivitas CTL dengan menghambat ekspresi gen sitotoksik (perforin, GzmA, GzmB, IFN $\gamma$, dan FasL) pada tingkat mRNA pada sel T CD8+ (Thomas dan Massagué, 2005).

- $\quad$ IL-10 merupakan sitokin imunosupresif yang yang disintesis sel Treg. IL-10 mempengaruhi beberapa mekanisme yang berkaitan dengan aktivasi sistem imun, diantaranya menghambat fungsi sel dendritik dengan menekan produksi sitokin inflamasi, menghambat MHC II, dan ekspresi molekul ko-stimulator. dimana IL-10 mempengaruhi imunitas bawaan dan adaptif untuk menurunkan respon imun terhadap antigen, kadar IL-10 juga didapatkan meningkat terutama pada HSIL (Dardalon et al., 2010).

\section{METODE PENELITIAN}

Salah satu piranti lunak melocular docking adalah DockingServer yang dapat diakses secara online melalui laman www.dockingserver.com. Aplikasi DockingServer dapat digunakan untuk analisis ligan tunggal serta untuk docking tingkat tinggi dari beberapa ligan untuk menargetkan suatu protein. DockingServer mengintegrasikan sejumlah perangkat lunak komputasi kimia yang secara khusus ditujukan untuk dapat menghitung parameter interaksi antar molekul dengan benar sehingga penggunaan DockingServer memungkinkan pengguna untuk melakukan perhitungan docking yang sangat efisien.

Langkah pertama dalam melakukan proses docking adalah mendownload file struktur ligan dan molekul target yang hendak kita uji di website http://pdb.org atau http://www.ncbi.nlm.nih.gov, dan disimpan dalam bentuk file pdb. Selanjutnya proses docking dilakukan secara online dengan membuka website DockingServer dengan alamat http://www.dockingserver.com/web, dan lakukan registrasi. File molekul ligan maupun 
protein target dimasukkan satu persatu, selanjutnya klik start docking. Proses ini membutuhkan waktu yang bervariasi, dari hitungan menit hingga berhari-hari. Bila proses yang dijalankan selesai akan ada notifikasi. Setelah output keluar dapat dilakukan analisis untuk menginterpretasikan hasil docking.

\section{HASIL DAN ANALISA}

Hasil prediksi interaksi molekuler antara CAPE dengan berbagai molekul target seperti IL-2, CD25, IL10, TGF $\beta$, CTLA-4, CCL21, dan IDO dengan menggunakan piranti lunak DockingServer memberikan beberapa informasi dari hasil proses docking diantaranya, free energy of binding yang artinya adalah jumlah/besar energi yang dibutuhkan ligan untuk berikatan dengan reseptor; makin kecil nilai free energy of binding menunjukkan prediksi potensi aktifitas ligan/substrat makin tinggi; inhibition concentration artinya konsentrasi ligan/substrat yang dibutuhkan untuk menghambat reseptor, makin kecil nilai inhibition concentration menunjukkan prediksi potensi aktifitas substrat makin tinggi, bila suatu proses docking tidak memberikan hasil nilai inhibition concentration maka kemungkinan senyawa tersebut bersifat agonis terhadap target; total intermolecular energy artinya total energi yang dibutuhkan dalam proses interaksi ligan reseptor, makin kecil nilai total intermolecular energy menunjukkan prediksi kemungkinan kecocokan interaksi ligan dengan reseptor makin tinggi; interaction surface artinya luas permukaan penempelan ligan dan reseptor, makin luas permukaan penempelan menunjukkan potensi interaksi ligan reseptor makin baik.

\subsection{CAPE (Caffeic acid phenethyl ester)}

Caffeic acid phenethyl ester atau juga dikenal dengan nama Phenethyl caffeate; CAPE atau Capeee merupakan salah satu senyawa aktif dalam propolis yang banyak diteliti dalam dunia pengobatan karena kemampuan antioksidan (Akyol et al., 2014; Ozkan et al., 2014), anti kanker (Ulasli et al., 2013; Chiang et al., 2014; Tseng et al., 2014), juga sebagai imunomodulator (Ansorge, Reinhold dan Lendeckel, 2003). CAPE memiliki rumus kimia $\mathrm{C}_{17} \mathrm{H}_{16} \mathrm{O}_{4}$, berat molekul $284.30654 \mathrm{~g} / \mathrm{mol}$, dan dapat larut dalam air (PubChem, NCBI).

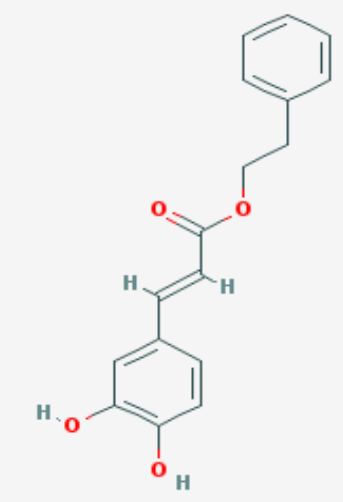

Gb. 1 Struktur kimia CAPE

3.2 Prediksi model interaksi antara CAPE dengan molekul target IL-2, CD25, IL-10, CTLA4, IDO, TGFß, dan CCL21 menggunakan software docking server

Hasil prediksi interaksi antara CAPE dengan berbagai molekul target menggunakan software docking server adalah sebagai berikut: 

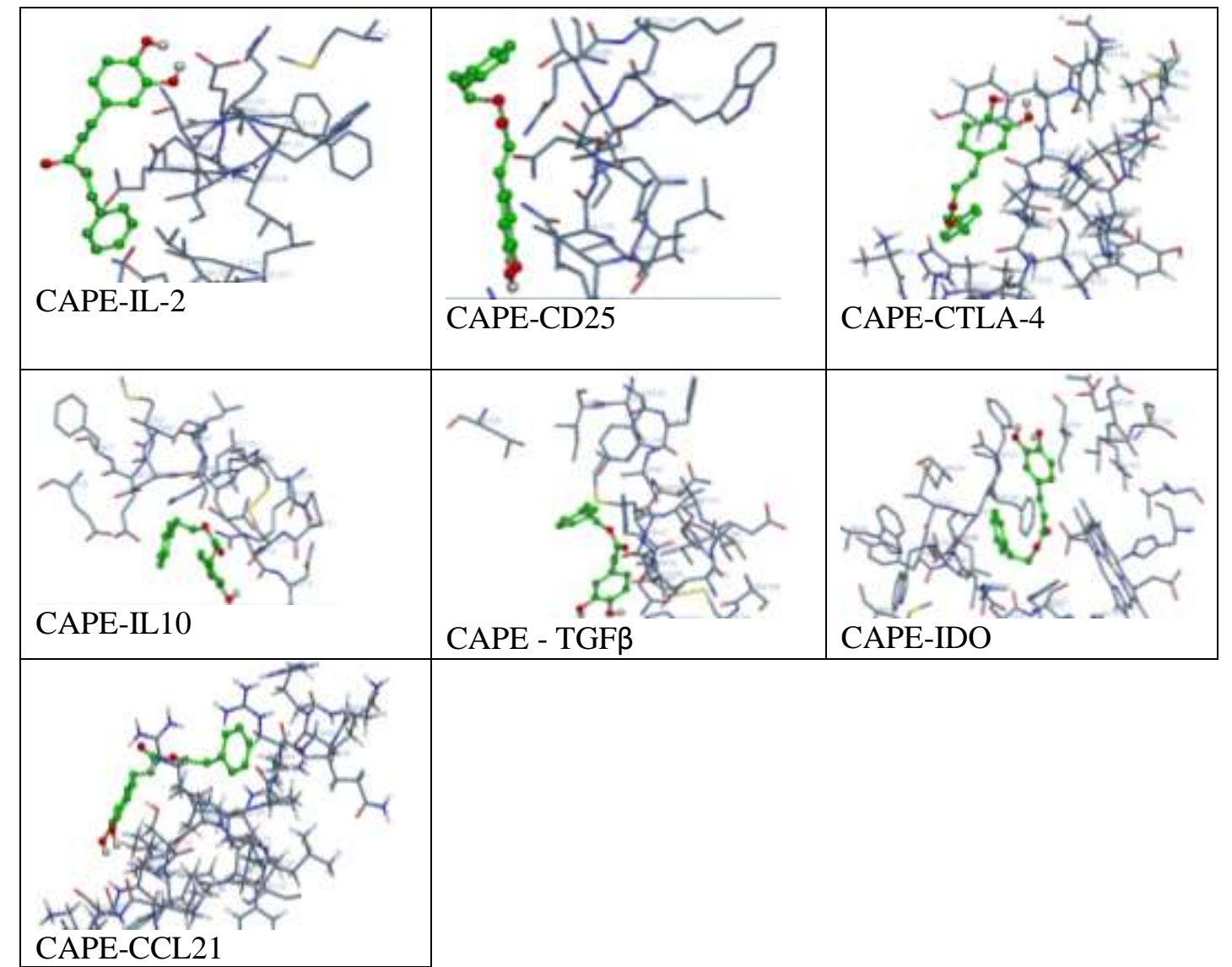

Gb. 2. Output molekuler docking antara CAPE dengan IL-2, CD25, IL-10, CTLA-4, IDO, TGFß, dan CCL21 dengan menggunakan software DockingServer

Tabel 1. Tabulasi molekuler docking CAPE dengan IL-2, CD25, IL-10, CTLA-4, IDO, TGF $\beta$, dan CCL21 dengan menggunakan software DockingServer.

\begin{tabular}{|c|c|c|c|c|c|}
\hline $\begin{array}{c}\text { Nama } \\
\text { ligand }\end{array}$ & $\begin{array}{c}\text { Molekul } \\
\text { Target }\end{array}$ & $\begin{array}{c}\text { Est.Free } \\
\text { Energi of } \\
\text { Binding } \\
(\mathrm{kcal} / \mathrm{mol})\end{array}$ & $\begin{array}{c}\text { Est.Inhibition } \\
\text { Constant }\end{array}$ & $\begin{array}{c}\text { Total } \\
\text { Intermolec.Energi } \\
(\mathrm{kcal} / \mathrm{mol})\end{array}$ & Interact.surface \\
\hline \multirow{5}{*}{ CAPE } & IL-2 & $-0,36$ & $547,43 \mathrm{mM}$ & $-2,58$ & 446,754 \\
\cline { 2 - 6 } & CD25 & 3,60 & - & 0,62 & 475,267 \\
\cline { 2 - 6 } & IL-10 & $-4,12$ & $949,96 \mu \mathrm{M}$ & $-5,22$ & 501,967 \\
\cline { 2 - 6 } & TGF & $-4,32$ & $684,78 \mu \mathrm{M}$ & $-5,69$ & 502,613 \\
\cline { 2 - 6 } & CTLA-4 & $-3,46$ & $2,90 \mathrm{mM}$ & $-5,00$ & 580,248 \\
\cline { 2 - 6 } & IDO & $-5,14$ & $171,86 \mu \mathrm{M}$ & $-6,54$ & 624,251 \\
\cline { 2 - 6 } & CCL21 & $-3,57$ & $2,41 \mathrm{mM}$ & $-5,44$ & 537.981 \\
\hline
\end{tabular}

Hasil docking CAPE dengan berbagai molekul diatas menunjukkan bahwa free binding energi terkecil terjadi antara CAPE dengan IDO $(-5,14)$, selanjutnya TGF $\beta$ dan IL-10 masingmasing $-4,32$ dan $-4,12$. Konstanta inhibisi masing-masing 171,86, 684,78 dan 949,96 untuk IDO, TGF $\beta$ dan IL-10. Sedang pada CD25 tidak muncul konstanta inhibisi artinya kemungkinan CAPE bersifat agonis pada molekul tersebut.

Dalam pengobatan terhadap kanker, CAPE dilaporkan memiliki aktifitas sitotoksik terhadap berbagai sel kanker diantaranya pada cell line kanker paru A549, $6 \mu \mathrm{g} / \mathrm{ml}$ CAPE menghambat pertumbuhan sebesar $60 \%$ dan menurunkan jumlah sel yang hidup sebesar $46 \%$ setelah inkubasi selama 48 jam (Chen et al., 2004). CAPE juga menginduksi apoptosis dan cell cycle arrest pada sel model kanker serviks ME180, CaSki, SiHa dan HeLa (Hsu et al., 2013). Pada sel model 
kanker payudara MCF-7 (ER+) dan MDAMB-231 (ER-/PR-/Her2-) ekstrak propolis menghambat deasetilasi histon dan menunjukkan hasil lebih poten dalam bentuk ekstrak propolis lengkap dibanding dengan CAPE (Omene, Wu dan Frenkel, 2012). Pada sel glioma CAPE menginduksi apoptosis dengan mengaktifkan p38 MAPK yang selanjutnya membentuk komplek dengan p53 dan memicu pelepasan cytocrome $\mathrm{C}$ (Tseng et al., 2014). CAPE juga merupakan inhibitor NFkB dimana aktifitas NFKB yang terkendali merupakan faktor penting dalam proliferasi sel normal namun aktivasi NFkB secara konstitutiv pada sel kanker menyebabkan peningkatan kemampuan pertumbuhan pada berbagai jenis sel kanker sel kanker (Bentires-alj et al., 2003).

\section{KESIMPULAN}

Secara virtual dengan menggunakan metode docking molekuler disimpulkan bahwa CAPE memiliki aktifitas inhibisi terhadap IL-2, CD25, IL-10, CTLA-4, IDO, TGF $\beta$, dan CCL2 sehingga berpotensi untuk dikembangkan lebih lanjut sebagai kandidat terapi imuomodulator terhadap kanker. 


\section{DAFTAR PUSTAKA}

Akyol, S. et al. (2014) "Caffeic Acid Phenethyl Ester as a Protective Agent against Nephrotoxicity and / or Oxidative Kidney Damage : A Detailed Systematic Review," The Scientific World Journal.

Ansorge, S., Reinhold, D. dan Lendeckel, U. (2003) "Propolis and Some of its Constituents DownRegulate DNA Synthesis and Inflammatory Cytokine Production but Induce TGF- 1 Production of," Z. Naturforchforsch.

Bentires-alj, M. et al. (2003) "NF- j B transcription factor induces drug resistance through MDR1 expression in cancer cells," hal. 90-97. doi: 10.1038/sj.onc.1206056.

Borges, K. S. et al. (2011) "Antiproliferative effects of Tubi-bee propolis in glioblastoma cell lines," 314, hal. 310-314.

Chen, M. et al. (2004) "Cell Killing and Radiosensitization by Caffeic Acid Phenethyl Ester ( CAPE ) in Lung Cancer Cells," 45(2), hal. 253-260.

Chen, Y. dan Guillemin, G. J. (2010) "Kynurenine Pathway Metabolites in Humans : Disease and Healthy States," 61(02).

Chiang, E. I. et al. (2014) "Caffeic Acid Derivatives Inhibit the Growth of Colon Cancer: Involvement of the PI3-K / Akt and AMPK Signaling Pathways," 9(6). doi: 10.1371/journal.pone.0099631.

Curti, A. et al. (2007) "Modulation of tryptophan catabolism by human leukemic cells results in the conversion of CD25 - into CD25 + T regulatory cells Modulation of tryptophan catabolism by human leukemic cells results in the conversion of CD25 $\mathrm{X}$ into CD25 $2 \mathrm{~T}$ regulatory cells," blood, 109, hal. 2871-2877. doi: 10.1182/blood-2006-07-036863.

Dardalon, V. et al. (2010) "Interleukin 4 Inhibit TGFb-induced-Foxp3+ T cells and generates, in combination with TGFb, Foxp3- effector T cells that produce interleukins 9 and 10," Nat Immunol, 9(12), hal. 1347-1355. doi: 10.1038/ni.1677.Interleukin.

Feinerman, O. et al. (2010) "Single-cell quantification of IL-2 response by effector and regulatory $\mathrm{T}$ cells reveals critical plasticity in immune response.," Molecular systems biology, 6, hal. 437. doi: $10.1038 / \mathrm{msb} .2010 .90$.

Hasson, S. O. (2014) "ANTIBACTERIAL ACTIVITIES OF IRAQI PROPOLIS AND ITS ACTIVE COMPONENTS EXTRACTS ON SOME BACTERIAL ISOLATES ( IN VITRO STUDY )," World Journal of Pharmacy and Pharmaceutical Science, 3(2), hal. 858-875.

Heo, L. et al. (2014) "GalaxySite : ligand-binding-site prediction by using molecular docking," Nucleic Acids research, 42(April), hal. 210-214. doi: 10.1093/nar/gku321.

Hsu, T. et al. (2013) "Caffeic acid phenethyl ester induces E2F-1-mediated growth inhibition and cell-cycle arrest in human cervical cancer cells," FEBS Journal, 280, hal. 2581-2593. doi: $10.1111 /$ febs. 12242 .

Khacha-ananda, S. et al. (2013) "Antioxidant and Anti-cancer Cell Proliferation Activity of Propolis Extracts from Two Extraction Methods," Asian Pac J Cancer Prev, 14(11), hal. 6991-6995.

Kodama, J. et al. (2007) "Association of CXCR4 and CCR7 chemokine receptor expression and lymph node metastasis in human cervical cancer," annals of Oncology, 18, hal. 70-76. doi: 10.1093/annonc/mdl342.

Kusnul, Z. et al. (2017) "Immunomodulatory Effect of Propolis Extract on population of IL-10 and TGFb Exression in CD4+CD25+ Regulatory T Cells in DMBA-induced Breast Cancer in Female Sprague-Dawley Rats,” Turkish Journal of Immunology, 5(3), hal. 69-76.

Mahajan, A., Gill, N. . dan Arora, R. (2014) "A REVIEW ON MOLECULAR DOCKING," International Journal of Recent Advances in Pharmaceutical research, 4(April), hal. 64-70.

Omene, C. O., Wu, J. dan Frenkel, K. (2012) "Caffeic Acid Phenethyl Ester ( CAPE ) derived from propolis, a honeybee product, inhibits growth of breast cancer stem cells," hal. 1279-1288. doi: 10.1007/s10637-011-9667-8.

Ozkan, U. et al. (2014) "Effects of intralipid and caffeic acid phenethyl ester on neurotoxicity , oxidative stress , and acetylcholinesterase activity in acute chlorpyriphos intoxication," Int $J$ Cin Exp Med, 7(4), hal. 837-846. 
Padmavathi, R. et al. (2006) "Therapeutic effect of paclitaxel and propolis on lipid peroxidation and antioxidant system in 7,12 dimethyl benz ( a ) anthracene-induced breast cancer in female Sprague Dawley rats," Life Science, 78, hal. 2820-2825. doi: 10.1016/j.1fs.2005.11.005.

Peghini, B. C. et al. (2012) "Local cytokine profiles of patients with cervical intraepithelial and invasive neoplasia," Human Immunology, 73(9), hal. 920-926. doi: 10.1016/j.humimm.2012.06.003.

Rosa, M. De et al. (2004) "Interleukin-2 is essential for CD4 + CD25 + regulatory T cell function," Eur.J.Immunol, 34, hal. 2480-2488. doi: 10.1002/eji.200425274.

Roy, S. et al. (2013) "Neem leaf glycoprotein overcomes indoleamine 2,3 dioxygenase mediated tolerance in dendritic cells by attenuating hyperactive regulatory $\mathrm{T}$ cells in cervical cancer stage IIIB patients," Human Immunology, 74(8), hal. 1015-1023. doi: 10.1016/j.humimm.2013.04.022.

Salatino, A. et al. (2005) "Origin and Chemical Variation of Brazilian Propolis," eCAM, 2(1), hal. 33-38. doi: 10.1093/ecam/neh060.

Sawaya, A. C. H. F., Barbosa da Silva Cunha, I. dan Marcucci, M. C. (2011) "Analytical methods applied to diverse types of Brazilian propolis.," Chemistry Central journal, 5(1), hal. 27. doi: 10.1186/1752-153X-5-27.

Sforcin, J. M., Kaneno, R. dan Funari, S. R. C. (2011) “ABSENCE OF SEASONAL EFFECT ON THE IMMUNOMODULATORY ACTION OF BRAZILIAN PROPOLIS ON NATURAL KILLER ACTIVITY .," (8), hal. 1-6. doi: 10.1590/S0104-79302002000100003.

Thomas, D. A. dan Massagué, J. (2005) "TGF- $\beta$ directly targets cytotoxic T cell functions during tumor evasion of immune surveillance," 8(November), hal. 369-380. doi: 10.1016/j.ccr.2005.10.012.

Tran, D. Q. et al. (2010) "Analysis of adhesion molecules, target cells and role of interleukin-2 in human FOXP3+ regulatory T cell suppressor function.," J Immunol, 182(5), hal. 2929-2938. doi: 10.4049/jimmunol.0803827.Analysis.

Tseng, T. et al. (2014) "Activation of neutral-sphingomyelinase, MAPKs , and p75 NTRmediating caffeic acid phenethyl ester - induced apoptosis in C6 glioma cells," Journal of Biomedical Science, 21(1), hal. 1-11. doi: 10.1186/1423-0127-21-61.

Ulasli, S. S. et al. (2013) "Anticancer Effects of Thymoquinone , Caffeic Acid Phenethyl Ester and Resveratrol on A549 Non-small Cell Lung Cancer Cells Exposed to Benzo ( a ) pyrene," Asian Pac J Cancer Prev, 14, hal. 6159-6164.

Wang, J. et al. (2004) "Expression Pattern of Chemokine Receptor 6 ( CCR6 ) and CCR7 in Squamous Cell Carcinoma of the Head and Neck Identifies a Novel Metastatic Phenotype," Cancer Res, 6, hal. 1861-1866.

Yasuda, T. et al. (2006) "Chemokines CCL19 and CCL21 promote activation-induced cell death of antigen-responding T cells," Blood, 109, hal. 449-456. doi: 10.1182/blood-2006-04-018101.

Zhou, S. et al. (2013) "CCR7 Expression and Intratumoral FOXP3 + Regulatory T Cells are Correlated with Overall Survival and Lymph Node Metastasis in Gastric Cancer," PLOS one, 8(9), hal. 1-7. doi: 10.1371/journal.pone.0074430. 